\title{
Educators' Preparation to Teach, Perceived Teaching Presence, and Perceived Teaching Presence Behaviors in Blended and Online Learning Environments
}

\author{
Lisa E. Gurley \\ William Carey University
}

\begin{abstract}
Teaching in blended and online learning environments requires different pedagogical approaches than teaching in face-to-face learning environments. How educators are prepared to teach potentially impacts the quality of instruction provided in blended and online learning courses. Teaching presence is essential to achieving student learning outcomes, yet previous research has focused on student perceptions of teaching presence. Therefore, the purpose of this mixed methods convergent parallel study was to explore educators' preparation to teach, perceived teaching presence, and perceived teaching presence behaviors in blended and online learning environments. The study was designed to examine the differences in educators' perceived teaching presence and preparation to teach in blended and online learning environments. An adapted Community of Inquiry survey instrument was used to measure faculty perceptions of teaching presence. Results indicated a statistically significant difference between perceived teaching presence of facilitation for faculty that completed certification courses in preparation to teach in blended and online learning environments, as compared to faculty that only received on-the-job training. Qualitative responses to corresponding interview questions supported the findings. The findings of this study provide information to university educators and administrators supporting the importance of faculty preparation specific to teaching in blended and online learning environments.
\end{abstract}

Keywords: teaching presence, teaching presence behaviors, teaching presence of facilitation, certified online instructor, faculty perceptions, blended learning, online learning, faculty development, faculty preparation, Community of Inquiry instrument, Community of Inquiry framework

Gurley, L.E. (2018). Educators' preparation to teach, perceived teaching presence, and perceived teaching presence behaviors in blended and online learning environments. Online Learning, 22(2), 197-220. doi:10.24059/olj.v22i2.1255

\footnotetext{
Author Note

Dr. Gurley is now Assistant Professor and Director, Accelerated Second-Degree BSN Program in the Ida Moffett School of Nursing, Samford University, Birmingham, Alabama.
} 
Educators' Preparation to Teach, Perceived Teaching Presence, and Perceived

Teaching Presence Behaviors in Blended and Online Learning Environments

\section{Educators' Preparation to Teach, Perceived Teaching Presence, and Perceived Teaching Presence Behaviors in Blended and Online Learning Environments}

The trend for distance education is increasing in higher education (American Association of Colleges of Nursing [AACN], 2003; McDonald \& Picciano, 2014; U.S. Department of Education, 2014). In 2012, the National Center for Education Statistics reported 11.1\% $(1,807,860)$ of degree- or certificate-seeking students enrolled in Title IV institutions were enrolled exclusively in distance education courses, $15.2 \%(2,466,785)$ were enrolled in some distance education courses, and $73.7 \%(11,950,900)$ were enrolled in non-distance-education courses (U.S. Department of Education, 2014). The number of private nonprofit institutions with online offerings had the greatest increase, with a doubling of the proportion with fully online programs - from $22.1 \%$ in 2002 to $48.4 \%$ in 2012 (Allen \& Seaman, 2013). The number of students enrolled in distance education courses is expected to increase (AACN, 2003; Allen \& Seaman, 2013; Allen, Seaman, Poulin, \& Straut, 2016).

Increased delivery and expectations for distance education (AACN, 2003; McDonald \& Picciano, 2014; U.S. Department of Education, 2014) have prompted administrators and faculty in higher education to voice concerns related to the quality of these courses (Allen \& Seaman, 2013; Allen et al., 2016). Course quality is influenced by teaching presence. Teaching presence behaviors for blended and online learning environments differ from the face-to-face classroom, as educators must effectively communicate when separated from students by time and place. According to the Community of Inquiry (CoI) framework, teaching presence includes the constructs of design and organization, facilitation of learning, and direct instruction (Garrison, Anderson, \& Archer, 2000). Effective design and organization of blended and online courses requires educators to thoughtfully and intentionally select course content, design learning activities, design evaluation activities, and establish a course calendar that is congruent with blended and online course delivery (Arbaugh et al., 2008; Garrison, Cleveland-Innes, \& Fung, 2010). Effective facilitation of learning in blended and online courses requires educators to engage in activities during the course that help students build a deeper level of understanding (Swan et al., 2008). Reviewing student discussion posts and completed course assignments and then providing reflective feedback are methods of facilitating learning (Garrison et al., 2010). Effectively directing instruction during blended and online courses requires educators to constantly evaluate student achievement of learning outcomes and provide timely instructional feedback (Arbaugh et al., 2008; Garrison et al., 2010). Feedback to students should encourage reflection and confirm learners' understanding (Garrison et al., 2010).

How educators are prepared to teach in blended and online learning environments impacts indicators of course quality, such as achievement of student learning outcomes and student satisfaction (Dereshiwsky, 2013). Methods for faculty preparation range from formal certification courses and faculty development programs to informal mentoring and on-the-job training (Dereshiwsky, 2013). The increase in blended and online course delivery in higher education places an increased burden on educators to design and organize courses, facilitate learning, and provide direct instruction for students separated by time and place. Understanding educators' perceived teaching presence and its associated behaviors is necessary to address how to best prepare faculty for teaching in blended and online learning environments in higher education.

Therefore, the purpose of this study was to explore educators' preparation to teach, perceived teaching presence, and perceived teaching presence behaviors in blended and online learning environments. The CoI framework (Figure 1), developed by Garrison, Anderson, and 
Archer (2000), provided the theoretical framework for this study. The CoI framework was developed to describe the necessary components of an ideal learning experience in an asynchronous, virtual higher education environment and has been used extensively to guide conceptualization of the online learning environment. Congruent with the principles of collaborative constructivism, a community of inquiry is made up of teachers and students working together for an educational purpose (Swan, Garrison, \& Richardson, 2009). Critical thinking and practical inquiry are at the foundation of the CoI framework (Shea, Vickers, \& Hayes, 2010), which hypothesizes that direct instruction alone is insufficient for knowledge construction in online environments. The depth of knowledge construction is dependent on the ability of teachers and learners to establish social presence, teaching presence, and cognitive presence (Shea \& Bidjerano, 2009). Educators must be intentionally present by selecting meaningful course resources, promoting student-student and student-faculty interactions, and guiding students through self-directed learning (O'Neil, 2014). Teaching presence is integral for higher level learning to occur (Garrison \& Cleveland-Innes, 2005). Results of this study help to fill the gap in the literature and support the necessity of faculty development programs in improving faculty transitions from face-to-face learning environments to blended and online learning environments.

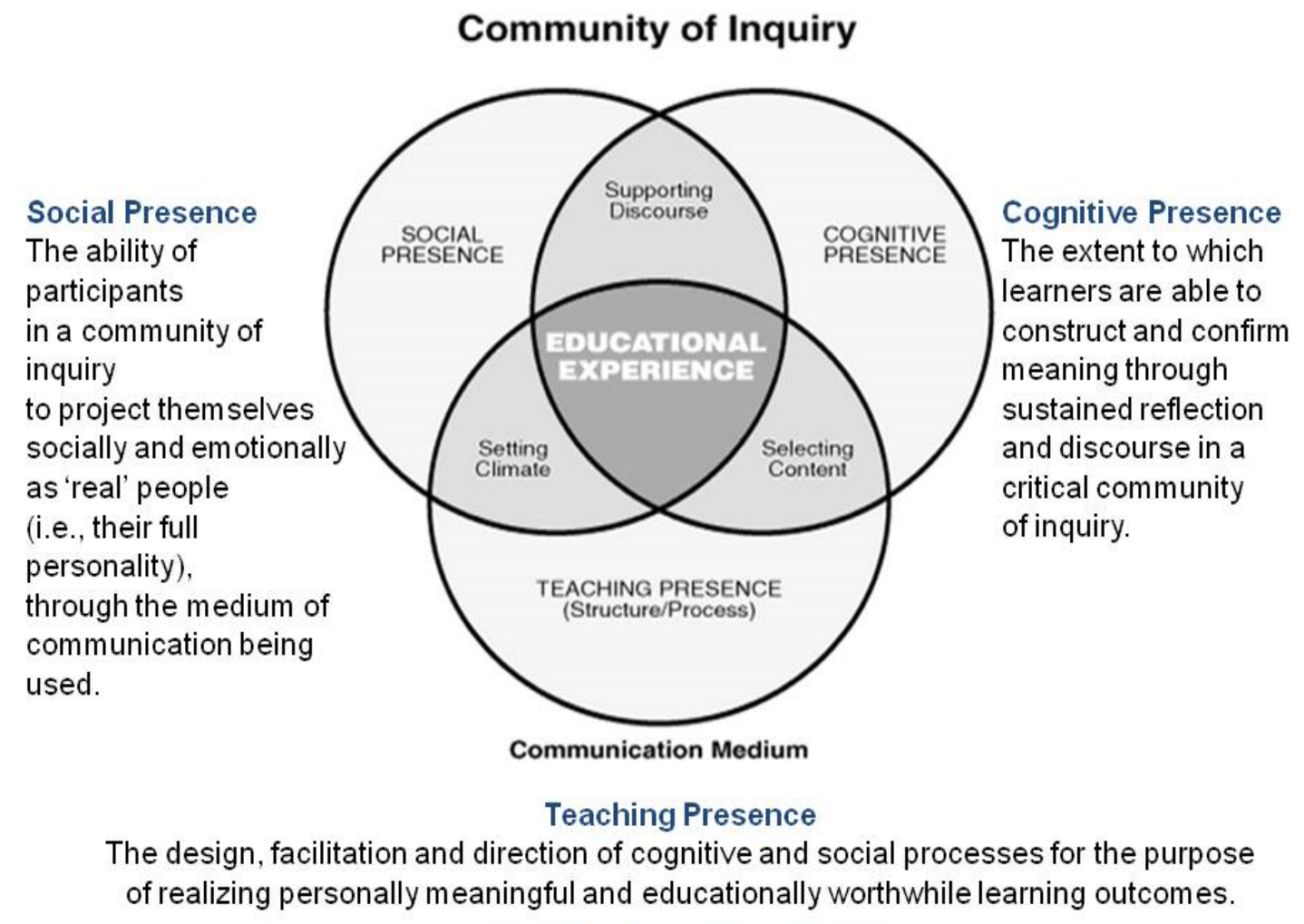

Garrison, Anderson and Archer (2000)

Figure 1. Community of Inquiry framework. Permission was received to use this figure. 
Educators' Preparation to Teach, Perceived Teaching Presence, and Perceived

Teaching Presence Behaviors in Blended and Online Learning Environments

\section{Review of Related Literature}

Review of the literature provides supporting evidence of the need to explore educators' preparation to teach, perceived teaching presence, and perceived teaching presence behaviors in blended and online learning environments. The literature lacks exploration of teaching presence from the educator's perspective, with most studies exploring the student's perspective. Most of the literature addressing how educators are prepared for teaching in blended and online learning environments is from primary and secondary education settings (Luo, Hibbard, Franklin, \& Moore, 2017; Shepherd, Bolliger, Dousay, \& Persichitte, 2016). Research has shown that teaching in blended and online learning environments requires different pedagogical approaches (theories, methods, and activities) than teaching face-to-face (Dereshiwsky, 2013; Sadera, O'Neil, \& Gould, 2014) and is often more challenging (Allen \& Seaman, 2013; Costello et al., 2014; Swan et al., 2008). Challenges to teaching from a distance are often related to the absence of nonverbal methods of communication, such as facial expressions and voice inflections (Rovai \& Jordan, 2004). In face-to-face learning environments, these nonverbal cues help guide facilitation of student learning and direct instruction. Through teaching presence behaviors, faculty help students interact socially and emotionally despite the use of technology (Garrison et al., 2000). Teaching presence behaviors also guide learners through the processes of knowledge construction, reflection, and discussion (Garrison et al., 2000). Teachers are ultimately responsible for establishing and maintaining teaching presence (Anderson, Rourke, Garrison, \& Archer, 2001).

\section{Blended and Online Learning}

Blended and online learning are modalities of distance education. Distance education has been defined as "education that uses one or more technologies to deliver instruction to students who are separated from the instructor and to support regular and substantive interaction between the students and the instructor synchronously or asynchronously" (U.S. Department of Education, 2014 , p. 1). Blended courses have been defined as courses that incorporate face-to-face class meetings with online learning activities, with at least $30 \%$ to $79 \%$ of the course materials and activities delivered online (Allen \& Seaman, 2013). Allen and Seaman (2013) defined online courses as having at least $80 \%$ of the course materials and activities completed online with limited face-to-face meetings.

\section{Preparation to Teach}

Traditional methods for preparing educators to teach are not sufficient or appropriate for blended and online learning environments (Baran \& Correia, 2014; Baran, Correia, \& Thompson, 2013). Teaching in blended and online learning environments requires different pedagogical approaches than teaching in face-to-face learning environments (Baran \& Correia, 2014; Baran et al., 2013). Pedagogical approaches include learner-centered learning theories, teaching and learning methods, and methods for evaluating learning outcomes (Shea, Li, Swan, \& Pickett, 2005). The CoI framework describes teaching presence as consisting of pedagogical approaches that help learners progress through the process of critical inquiry or deep learning (Garrison et al., 2000). Often, educators who perceive themselves as expert teachers in face-to-face classrooms perceive themselves as novice teachers in virtual classrooms (Ali et al., 2005). Effectively teaching in the virtual classroom requires educators to reconceptualize the role of teacher (Ali et al., 2005). Baran and Correia (2014) proposed that some organizations will need a cultural change in support of faculty members transitioning from face-to-face to online learning environments. Literature describing levels of preparation to teach in blended and online learning environments is lacking, 
yet the literature does indicate that teacher preparation specific to the online classroom is necessary to provide high-quality learning environments (Ali et al., 2005; Baran et al., 2013).

Several studies have demonstrated the importance of preparation to teach in blended and online learning environments through exploration of changes in faculty role, pedagogies (Ryan, Hodson-Carlton, \& Ali, 2004), and perceived level of teaching expertise (Ali et al., 2005) when transitioning to an online teaching environment. Ryan, Hodson-Carlton, and Ali (2004) revealed the following six dimensions of teaching online that must be considered when faculty move from face-to-face learning environments to online classrooms: addressing faculty role issues, redesigning/rethinking courses, handling communications, developing partnerships, managing time, and dealing with technology. Using the six dimensions identified by Ryan et al. (2004) and Benner's five-stage sequential transformation from novice to expert framework, Ali et al. (2005) assessed faculty's perceived level of teaching expertise in online learning environments, as well as priorities for faculty development. Results of the study revealed that faculty who reported teaching online scored higher for all dimensions than faculty who had not taught online. Participants ranked redesigning/rethinking faculty roles as the highest priority. The researchers concluded that faculty not teaching online perceived themselves as novice-to-advanced beginners in the online learning environment. Faculty teaching online perceived themselves as advanced beginners or competent in the online learning environment. Participants in this study did not perceive themselves as proficient or expert teachers in the online learning environment, even though they had previous experience in the face-to-face classroom.

Baran and Correia (2014) recognized the challenges faculty face when expected to master unfamiliar technical skills while developing course materials, learning activities, and evaluation methods appropriate for the online learning environment. The researchers developed a professional development framework for online teaching based on research supporting best practices in online teaching and faculty preferences for professional development activities. The professional development framework for online teaching provides a holistic approach that guides support of teaching, community, and organizations. Baran and Correia (2014) proposed that administrators must provide support and professional development programs that not only address technologies but also pedagogies specific to utilization of the technologies. In addition, faculty must receive support at the community level (peer support and mentoring) because teaching in the online environment can lead to isolation from other faculty members. Organizational support is necessary, especially for novice online faculty, to recognize the increased workload and time commitment of faculty learning unfamiliar technologies and pedagogies (Baran \& Correia, 2014). These studies support faculty development as a priority in preparing faculty to teach in the online learning environment and support the need to explore how faculty are currently prepared to teach in blended and online learning environments.

\section{Teaching Presence}

Limited research has been conducted on teaching presence in the online learning environment (Campbell, 2014). Much of the research related to teaching presence has focused completely on the contents of threaded discussions (Shea et al., 2010), thus neglecting other indicators of teaching presence. Indicators of teaching presence (design and organization, facilitation, and direct instruction) have been used to measure how visible the instructor is in the online learning environment from the student's perspective. Several studies have identified teaching presence as a predictor of student perceptions of satisfaction, learning, and connectedness 
(Akyol \& Garrison, 2008; Arbaugh, 2008; Saint-Jacques, 2013; Shea \& Bidjerano, 2009; Sheridan, Kelly, \& Bentz, 2013).

Research related to faculty perceptions of teaching in an online environment have primarily focused on faculty satisfaction (Bolliger \& Wasilik, 2009). The Online Learning Consortium, formerly the Sloan Consortium, has identified faculty satisfaction as one of the five pillars for achieving quality in online education (Moore, 2010). According to Moore (2010), faculty satisfaction in online learning environments reflects a strong institutional commitment to promoting personal and professional growth of faculty.

Bolliger and Wasilik (2009) utilized the Sloan Consortium's Quality Framework for Online Education as the theoretical framework to explore issues that affect teaching in the online learning environment, including factors influencing faculty satisfaction with teaching online. Consistent with the literature related to faculty satisfaction in the online environment, the survey items addressed three subscales of faculty satisfaction: student-related issues, instructor-related issues, and institution-related issues. Results of the study were consistent with the literature related to perceived faculty satisfaction. Student-related issues, such as flexible and convenient course access, were indicated as most important in measuring perceived faculty satisfaction. Studentrelated issues were found to impact perceived faculty satisfaction more than instructor-related issues. Based on the relationship between the student factor and faculty satisfaction, the researchers concluded a student-centered approach is necessary in online instruction.

Shea, Vickers, and Hayes (2010) used a revised CoI framework to measure productive instructional effort through analysis of instructor and student interactions in online courses. Data sources included discussion forums, small-group student discussion areas, full-group discussion, course announcements, private student-instructor communications, public questions, syllabi, and all instructional materials. Results indicated that teaching presence and instructional efforts occurred more often in communications outside of discussion posting in both courses. In addition, a statistically significant correlation was revealed between the expression of teaching presence and assignment grades of the students. These studies support the importance of student-centered pedagogies in facilitating teaching presence in the online learning environment. In addition, there is a need to explore faculty perceptions of teaching presence, and when and where instructional effort is most focused.

Several studies have described specific teaching presence behaviors. In 2013, Arinto conducted a qualitative study exploring pedagogical rationales for faculty use of web technologies, approaches to course design, perspectives on how course design approaches have changed, challenges of changing course design approaches, and implications for faculty development. The study explored perceptions of how faculty teaching practices have evolved during the transition from face-to-face to online learning. Analysis of the interview transcripts revealed four areas of change in course design practices: content development, learning activities, teaching strategies, and assessment. Based on the study results and literature on faculty development, Arinto proposed a framework for developing open and distance e-learning course competencies for faculty at universities transitioning to online learning. The framework included examples of each competency at the basic, intermediate, and advanced proficiency levels. Arinto recommended future research related to holistic and integrated faculty development programs to prepare faculty for teaching in online learning environments. 
Similarly, Baran, Correia, and Thompson (2013) conducted a qualitative study exploring the successful teaching practices, challenges, concerns, and solutions of six expert online teachers. The university had a decentralized online education policy; thus, online teachers implemented a variety of approaches and strategies. Interview questions were related to "program organization, student and faculty profiles, faculty support and professional development services, course design processes, and technology platforms" (Baran et al., 2013, p. 8). Following the interviews, program coordinators nominated exemplary online teachers, supported with criteria for success. The six top-ranked teachers described how they transitioned into successfully teaching in the online learning environment. Data analysis of the program coordinators' transcripts revealed criteria for nominating exemplary online teachers: "knowledge of students, knowledge of content, effective communication with the students, and high scores on the course evaluations" (Baran et al., 2013, p. 11). Within- and cross-case analysis of the online teachers' transcripts revealed the following concerns and challenges related to transitioning to the online learning environment: "knowing and creating the course content, designing and structuring the online course, knowing the students, enhancing student-teacher relationships, guiding student learning, evaluating online courses, and maintaining teacher presence" (Baran et al., 2013, p. 11). This study supports the importance of challenging traditional pedagogical beliefs and practices and of exploring best practices for preparing and supporting faculty to teach in the online learning environment.

\section{Community of Inquiry Survey Instrument}

The literature supports the CoI Survey instrument as reliable for measuring teaching presence (Arbaugh et al., 2008; Carlon et al., 2012; Shea \& Bidjerano, 2009). Reliability has been supported with Cronbach's alpha reported as .95 for cognitive presence, .96 for teaching presence, and .92 for social presence (Shea \& Bidjerano, 2009); .95 for cognitive presence, .94 for teaching presence, and .91 for social presence (Arbaugh et al., 2008); and .927 for cognitive presence, .966 for teaching presence, . 944 for social presence (Carlon et al., 2012). These studies support the CoI Survey instrument as a valid tool for identifying learners' perceptions of cognitive presence, teaching presence, and social presence in a variety of disciplines and educational settings, thus adding strength to the generalizability of the instrument.

Review of the literature clearly identifies traditional pedagogical approaches as ineffective in facilitating teaching presence in blended and online learning environments (Shea et al., 2005). Teaching presence is a necessary element in facilitating quality instruction and student satisfaction. Yet, research related to how educators perceive their ability to achieve teaching presence and which behaviors educators believe facilitate teaching presence in blended and online learning environments is lacking. This study addresses the gap in the literature by exploring educators' perceptions of how well they facilitate teaching presence and specific behaviors associated with facilitating teaching presence in blended and online learning environments. Therefore, the following research questions and hypotheses guided the study:

1. What preparation to teach in blended and online learning environments have educators received?

2. What behaviors do educators perceive as facilitating teaching presence in blended and online learning environments?

Hypothesis 1: There is no statistically significant difference between educators' overall perceived teaching presence based on preparation to teach in blended and online learning environments. 
Hypothesis 2: There is no statistically significant difference between educators' perceived teaching presence of design and organization based on preparation to teach in blended and online learning environments.

Hypothesis 3: There is no statistically significant difference between educators' perceived teaching presence of facilitation based on preparation to teach in blended and online learning environments.

Hypothesis 4: There is no statistically significant difference between educators' perceived teaching presence of direct instruction based on preparation to teach in blended and online learning environments.

\section{Study Population}

\section{Methods}

The sample population for this research study was a convenience sample of full-time, parttime, and adjunct educators who have taught one or more undergraduate or graduate level blended or online course within the past 5 years at two private universities in the southeastern United States. The selection of the population sample is supported by the literature showing the greatest increase in online courses and fully online programs having occurred in private nonprofit institutions (Allen \& Seaman, 2013; Allen et al., 2016). Educators teaching in all disciplines or schools within the universities were included in the sample population. Power analysis was performed to determine the minimum sample size needed for the quantitative data to be significant (MaCorr Research Solutions Online, 2015), which was determined to be 80 . Of the 100 estimated full-time, part-time, and adjunct educators that have taught at least one blended or online course within the past 5 years, $86(86 \%)$ responded to the survey, exceeding the minimum adequate sample size. Table 1 summarizes the teaching demographics.

\section{Table 1.}

\section{Frequency Distribution of Participant Teaching Demographics $(N=86)$}

\begin{tabular}{lr}
\hline Teaching Demographic Characteristics & $n(\%)$ \\
\hline Preparation to teach (select all that apply) & $86(100.0)$ \\
None & $0(0.0)$ \\
Informal on-the-job training & $68(79.1)$ \\
Some college courses & $26(30.2)$ \\
Professional development program & $61(70.9)$ \\
Certification course & $29(33.7)$ \\
Certification to teach blended/online courses & \\
$\quad$ No & $86(100.0)$ \\
$\quad$ Yes & $57(66.3)$ \\
Teaching level & $29(33.7)$ \\
$\quad$ Undergraduate & \\
Graduate & $86(100.0)$ \\
Both & $20(23.3)$ \\
& $29(33.7)$ \\
\end{tabular}




\begin{tabular}{lr}
\hline Table 1. (cont.) & \\
Frequency Distribution of Participant Teaching Demographics $(N=86)$ & $n(\%)$ \\
\hline Teaching Demographic Characteristics & $86(100.0)$ \\
\hline Years teaching in higher education & $8(9.3)$ \\
0-3 years & $11(12.8)$ \\
3-6 years & $18(20.9)$ \\
6-10 years & $49(57.0)$ \\
10 years or more & \\
Employment status & $86(100.0)$ \\
Full-time & $76(88.4)$ \\
Part-time & $4(4.7)$ \\
Adjunct & $6(7.0)$ \\
Blended courses taught past 5 years & \\
None & $86(100.0)$ \\
One & $9(10.5)$ \\
Two & $12(14.0)$ \\
Three or more & $17(19.8)$ \\
& $48(55.8)$ \\
Online courses taught past 5 years & \\
None & $86(100.0)$ \\
One & $9(10.5)$ \\
Two & $14(16.3)$ \\
Three or more & $8(9.3)$ \\
& $55(64.0)$ \\
\hline
\end{tabular}

\section{Data Collection}

Institutional Review Board for the Protection of Human Subjects in Research (IRB) approval was obtained from the participating universities for both the pilot and study. Data were collected through an online survey and open-ended questions administered through Qualtrics research platform to ensure the security and anonymity of the data. No identifying information was collected.

This study used a mixed methods convergent parallel research design. The convergent research design is the most common mixed methods design used by researchers new to mixed methods (Creswell \& Plano Clark, 2011). In convergent research design, both quantitative and qualitative data are collected at the same time, analyzed separately, and then merged (Creswell, 2014). Merging quantitative statistical results with qualitative findings provides a method for further substantiating, explaining, and understanding statistical relationships. Strengths of utilizing this design include ease of use and efficiency of data collection and analysis. Convergent design is appropriate when limited time is available for data collection, and both quantitative and qualitative data are valuable in understanding the problem. Quantitative data were collected via an Adapted CoI Survey Instrument. Qualitative data were collected via open-ended questions asking participants to share their personal experiences related to teaching behaviors in blended and online courses. 
An Adapted CoI Survey Instrument (Arbaugh et al., 2008), modified by this researcher, was used to measure educators' perceived teaching presence in blended and online learning environments. The CoI Survey instrument was originally designed to measure the three constructs of the CoI framework (social presence, teaching presence, and cognitive presence) from the students' perspective. Permission to adapt the CoI Survey instrument was granted by the authors of the survey. The original 13 closed-ended items measuring perceived teaching presence were reworded to address the educator's perception. Participants were asked to rate to what degree they consistently achieve the teaching presence behaviors associated with course design and organization, facilitation of learning, and direct instruction. Ratings were on a scale of 1 (strongly disagree) to 4 (strongly agree). The rating of neutral was removed from the original CoI Survey instrument. One categorical item targeting educators' formal and informal preparation to teach in blended and online learning environments was included. Teaching experience in blended and online courses was examined. Participants were invited to respond to open-ended questions and asked to share personal experiences related to teaching behaviors in blended and online courses.

The Adapted CoI Survey Instrument was reviewed for content and face validity by two experts not involved with this study. One expert has extensive experience as an online educator and is familiar with the CoI framework through past research endeavors. One expert has extensive experience as an online educator, has completed college courses related to online teaching, has completed an online teaching certificate course, and has earned certification to teach online courses. Both experts hold doctoral degrees in nursing education. Major revisions to the Adapted CoI Survey Instrument were not recommended.

Following expert review, a pilot study was conducted to validate the reliability of the instrument in measuring perceived teaching presence. The research study was conducted following the pilot. The dean or chair of each school or program at the participating universities was contacted via email to request permission to allow faculty to participate in the research. The email to the faculty introduced the research topic, provided information about the purpose and significance of the study, and requested permission to participate. The link to the online survey and open-ended questions was contained in the email to faculty. Submission of responses indicated consent to participate. Data were collected through an online survey and open-ended questions administered through Qualtrics to ensure the security and anonymity of the data. No identifying information was collected. Data were collected from full-time, part-time, and adjunct university faculty that had taught at least one blended or online course within the past five years, thus representing the target population.

\section{Reliability}

Internal consistency for the Adapted CoI Survey Instrument was measured following collection of pilot study data. The Adapted CoI Survey Instrument was utilized to measure overall perceived teaching presence and the related constructs of design and organization, facilitation of learning, and direct instruction. The pilot study consisted of 21 participants. Overall perceived teaching presence consisted of 13 questions. The scale had a high level of internal consistency, as determined by Cronbach's alpha of .852 . The construct of design and organization consisted of four questions. The scale had a high level of internal consistency, as determined by Cronbach's alpha of .788. The construct of facilitation of learning consisted of six questions. The scale had a high level of internal consistency, as determined by Cronbach's alpha of .808. The construct of direct instruction consisted of three questions. The scale had a low level of internal consistency, 
as determined by Cronbach's alpha of .377. Due to the low level of internal consistency, the construct of direct instruction was not measured.

\section{Data Analysis}

Congruent with mixed methods convergent parallel research design, statistical analysis of quantitative data were performed separately from qualitative thematic content analysis. Statistical Package for the Social Sciences (SPSS) was used for quantitative statistical analysis. Following separate analysis of quantitative and qualitative data, results were merged.

Research Question 1 was addressed through descriptive statistical analysis. Research Question 2 was addressed through qualitative thematic content analysis of open-ended responses of survey items 1, 2, and 3 of Part III of the Adapted CoI Survey Instrument. Separate one-way analyses of variance were conducted to address Hypotheses 1, 2, and 3. Hypothesis 4 was not tested due to low reliability of Part I Questions 11 through 13 of the Adapted CoI Survey Instrument in measuring perceived teaching presence of direct instruction.

\section{Results}

\section{Descriptive Statistics of Dependent Variables}

The research study included four dependent variables: overall perceived teaching presence, perceived teaching presence of design and organization, perceived teaching presence of facilitation, and perceived teaching presence of direct instruction.

Overall perceived teaching presence was measured using survey items 1 through 13 of Part I of the Adapted CoI Survey Instrument. Participants rated level of agreement with these 13 statements from strongly disagree (1) to strongly agree (4). Perceived teaching presence of design and organization was measured using survey items 1 through 4 of Part I of the Adapted CoI Survey Instrument. Perceived teaching presence of facilitation was measured using survey items 5 through 10 of Part I of the Adapted CoI Survey Instrument. Perceived teaching presence of direct instruction was measured using survey items 11 through 13 of Part I of the Adapted CoI Survey Instrument. Table 2 presents the mean scores and standard deviations for each item representing participants' level of agreement with statements concerning overall perceived teaching presence. Table 3 presents comparison of the mean scores and standard deviations for each dependent variable. 
Table 2 .

Descriptive Statistics for Overall Perceived Teaching Presence, Survey Items 1-13 of Part I

Question $N \quad M \quad S D$

1. Overall, I clearly communicate $\quad 86 \quad 3.66 \quad .476$

important course topics.

2. Overall, I clearly communicate $\quad 86 \quad 3.67$

course goals.

$\begin{array}{llll}\text { 3. Overall, I provide clear } & 86 & 3.65 & .479\end{array}$

instructions on how to participate in

course learning activities.

4. Overall, I clearly communicate

86

3.81

.391

important due dates/time frames for

learning activities.

5. Overall, I am helpful in identifying

85

3.27

.543

areas of agreement and disagreement

on course topics that help students to

learn.

6. Overall, I am helpful in guiding

86

3.49

.526

the class towards understanding

course topics in a way that helps

students clarify their thinking.

7. Overall, I help to keep course

86

3.31

.637

participants engaged and

participating in productive dialogue.

8. Overall, I help keep the course

86

3.51

.503

participants on task in a way that

helps students learn.

9. Overall, I encourage course

86

3.35

.609

participants to explore new concepts

in courses.

10. Overall, my actions reinforce the

86

3.17

.654

development of a sense of

community among course

participants.

11. Overall, I help to focus

86

3.53

.567

discussion on relevant issues in a

way that helps students to learn.

12. Overall, I provide feedback that

86

3.44

.606

helps students understand their

strengths and weaknesses relative to

the course's goals and objectives.

13. Overall, I provide feedback in a

86

3.58

.583 timely fashion.

Scale: 1 (strongly disagree), 2 (disagree), 3 (agree), 4 (strongly agree) 


\section{Table 3.}

Comparison of Overall Perceived Teaching Presence, Perceived Teaching Presence of Design and Organization, Perceived Teaching Presence of Facilitation, and Perceived Teaching Presence of Direct Instruction

\begin{tabular}{lccc}
\hline Dependent Variable & $N$ & $M$ & $S D$ \\
\hline $\begin{array}{l}\text { Overall Perceived Teaching } \\
\text { Presence }\end{array}$ & 85 & 3.49 & .325 \\
$\begin{array}{l}\text { Perceived Teaching Presence of } \\
\text { Design and Organization }\end{array}$ & 86 & 3.70 & .355 \\
$\begin{array}{l}\text { Perceived Teaching Presence of } \\
\text { Facilitation }\end{array}$ & 85 & 3.35 & .406 \\
$\begin{array}{l}\text { Perceived Teaching Presence of } \\
\text { Direct Instruction }\end{array}$ & 86 & 3.52 & .398 \\
\hline
\end{tabular}

\section{Quantitative Findings}

For statistical analysis, the independent variable preparation to teach was grouped as three categories. Frequency distributions of preparation to teach as grouped for statistical analysis have been reported in Table 4.

\begin{tabular}{lr}
\hline \begin{tabular}{l} 
Table 4. \\
Frequency Distribution of Preparation to Teach as Grouped for Statistical Analysis $(N=86)$ \\
\hline
\end{tabular} & $N(\%)$ \\
\hline Preparation to teach & $86(100.0)$ \\
Informal on-the-job training only & $15(17.4)$ \\
Some college courses and/or professional development program & $43(50)$ \\
$\begin{array}{l}\text { Certification course and/or professional development program, } \\
\text { and/or some college courses, and/or informal on-the-job training }\end{array}$ & $28(32.6)$ \\
\hline
\end{tabular}

Hypothesis 1: There is no statistically significant difference between overall perceived teaching presence based on educators' preparation to teach in blended and online learning environments.

One-way analysis of variance was conducted to determine whether there was a statistically significant difference between overall perceived teaching presence based on educators' preparation to teach in blended and online learning environments. Data were analyzed based on participants perceived overall teaching presence score (survey items 1 through 13 of Part I) and preparation to teach in blended and online courses (survey item 1 of Part II). There was homogeneity of variances, as assessed by Levene's test for equality of variances $(p=.279)$. There was no statistically significant difference between educators' perceived overall teaching presence 
based on preparation to teach in blended and online learning environments, $F(2,82)=3.093, p=$ .051 .

Hypothesis 2. There is no statistically significant difference between perceived teaching presence of design and organization based on educators' preparation to teach in blended and online learning environments.

One-way analysis of variance was conducted to determine whether there was a statistically significant difference between perceived teaching presence of design and organization based on educators' preparation to teach in blended and online learning environments. Data were analyzed based on participants' perceived teaching presence of design and organization (survey items 1 through 4 of Part I) and preparation to teach in blended and online courses (survey item 1 of Part II). There was homogeneity of variances, as assessed by Levene's test for equality of variances ( $p$ $=.220$ ). There was no statistically significant difference between educators' perceived teaching presence of design and organization based on preparation to teach in blended and online learning environments, $F(2,83)=1.202, p=.306$.

Hypothesis 3. There is no statistically significant difference between perceived teaching presence of facilitation based on educators' preparation to teach in blended and online learning environments.

One-way analysis of variance was conducted to determine whether there was a statistically significant difference between perceived teaching presence of facilitation based on educators' preparation to teach in blended and online learning environments. Data were analyzed based on participants' perceived teaching presence of facilitation (survey items 5 through 10 of Part I) and preparation to teach in blended and online courses (survey item 1 of Part II). The assumption of homogeneity of variances was violated, as assessed by Levene's test for equality of variances ( $p=$ .038). There was a statistically significant difference between educators' perceived teaching presence of facilitation based on preparation to teach in blended and online learning environments, $F(2,82)=3.772, p=.027$. The perceived teaching presence of facilitation was statistically significantly different for different levels of the preparation to teach group, Welch's $F(2,42.970)$ $=5.492, p=.008$. Games-Howell post hoc analysis revealed a significant difference between perceived teaching presence of facilitation score of educators that received on-the-job training $(M$ $=3.13, S D=.28)$ as compared to educators that completed a certification course $(M=3.48, S D=$ .40). The mean increase of .35 for educators that completed a certification was statistically significant $(p=.006)$. Multiple comparisons in ANOVA for the independent variable of preparation to teach and the dependent variable of perceived teaching presence have been presented in Table 5. 
Educators' Preparation to Teach, Perceived Teaching Presence, and Perceived

Teaching Presence Behaviors in Blended and Online Learning Environments

\begin{tabular}{|c|c|c|c|c|c|c|c|}
\hline \multicolumn{8}{|c|}{$\begin{array}{l}\text { Table } 5 . \\
\text { Multiple Comparisons of Preparation to } \\
\text { Teaching Presence of Facilitation }\end{array}$} \\
\hline & \multirow[b]{2}{*}{ (I) Preparation to Teach } & \multirow[b]{2}{*}{ (J) Preparation to Teach } & \multirow[b]{2}{*}{$\begin{array}{c}\text { Mean } \\
\text { Difference } \\
(\mathrm{I}-\mathrm{J})\end{array}$} & \multirow[b]{2}{*}{ Std. Error } & \multirow[b]{2}{*}{ Sig. } & \multicolumn{2}{|c|}{$95 \%$ Confidence Interval } \\
\hline & & & & & & Lower Bound & Upper Bound \\
\hline \multirow[t]{5}{*}{ Tukey HSD } & \multirow[t]{2}{*}{ On-the-job-training } & $\begin{array}{l}\text { Some college and/or } \\
\text { professional development }\end{array}$ & -.21938 & .11805 & .157 & -.5012 & .0624 \\
\hline & & Certification course & $-.34815^{*}$ & .12677 & .020 & -.6508 & -.0455 \\
\hline & $\begin{array}{l}\text { Some college and/or } \\
\text { professional } \\
\text { development }\end{array}$ & $\begin{array}{l}\text { On-the-job training } \\
\text { Certification course }\end{array}$ & $\begin{array}{r}.21938 \\
-.12877\end{array}$ & $\begin{array}{l}.11805 \\
.09666\end{array}$ & $\begin{array}{l}.157 \\
.382\end{array}$ & $\begin{array}{l}-.0624 \\
-.3595\end{array}$ & $\begin{array}{l}.5012 \\
.1020\end{array}$ \\
\hline & \multirow[t]{2}{*}{ Certification course } & On-the-job training & $.34815^{*}$ & .12677 & .020 & .0455 & .6508 \\
\hline & & $\begin{array}{l}\text { Some college and/or } \\
\text { professional } \\
\text { development }\end{array}$ & .12877 & .09666 & .382 & -.1020 & .3595 \\
\hline \multirow[t]{6}{*}{ Games-Howell } & \multirow[t]{2}{*}{ On-the-job training } & $\begin{array}{l}\text { Some college and/or } \\
\text { professional development }\end{array}$ & -.21938 & .09717 & .075 & -.4567 & .0180 \\
\hline & & Certification course & $-.34815^{*}$ & .10633 & .006 & -.6076 & -.0887 \\
\hline & \multirow{2}{*}{$\begin{array}{l}\text { Some college and/or } \\
\text { professional } \\
\text { development }\end{array}$} & On-the-job training & .21938 & .09717 & .075 & -.0180 & .4567 \\
\hline & & Certification course & -.12877 & .10030 & .410 & -.3701 & .1126 \\
\hline & \multirow[t]{2}{*}{ Certification course } & On-the-job training & $.34815^{*}$ & .10633 & .006 & .0887 & .6076 \\
\hline & & $\begin{array}{l}\text { Some college and/or } \\
\text { professional } \\
\text { development }\end{array}$ & .12877 & .10030 & .410 & -.1126 & .3701 \\
\hline
\end{tabular}

*The mean difference is significant at the .05 level.

\section{Qualitative Findings}

Research Question 2 explored behaviors educators perceive as facilitating teaching presence in blended and online learning environments. Three open-ended questions addressed teaching presence behaviors of design and organization, facilitation, and direct instruction. The identified teaching presence behaviors were explored to better understand the phenomenon of teaching presence. The responses for each question were reviewed, compared, and contrasted to identify similarities and differences. Major themes were formed according to participants' responses.

Design and organization. Open-Ended Question 1 asked the following: Please describe how you provide clear communication of important course topics, goals, due dates, and instructions for participation in learning activities. The Adapted CoI Survey Instrument Quantitative Questions 1 through 4 of Part I provided the framework for survey item 1 of Part III. The qualitative data were analyzed to identify emerging themes.

Of the 86 study participants, $83.7 \%(n=72)$ responded to Interview Question 1. Four major themes emerged describing teaching presence behaviors of design and organization: providing a 
course syllabus, utilizing learning management system tools, providing a course orientation video, and email, phone, or video conferences or reminders. Exemplar participant responses to OpenEnded Question 1 representing each theme included the following:

P3: "Students are provided with all course documents, including a detailed syllabus that delineates what topics will be covered and the dates they should be prepared to cover those topics, what the goals/learning objectives are for each topic as well as the course in general, specific dates topics will be covered and when applicable how to access the information if it is provided via an electronic link or resource."

P38: "Documents are placed in the learning management system including a syllabus, faculty contact information, and a course calendar. An AV conference is held with students to go over these documents."

P75: "I provide a course orientation at the beginning of the course. This is either done in video recordings or in a conference. I also open up a discussion board to encourage questions regarding the syllabus, course calendar, course expectations."

Facilitation. Open-Ended Question 2 asked the following: Please describe how you facilitate student learning. For example, what teaching methods have worked well to engage students in course topics, clarify students' understanding, keep students on task, and encourage students to explore new concepts? The Adapted CoI Survey Instrument Quantitative Questions 5 through 10 provided the framework for Interview Question 2. The qualitative data were analyzed to identify emerging categories.

Of the 86 study participants, $83.7 \%(n=72)$ responded to Open-Ended Question 2. Three major themes emerged describing teaching presence behaviors of facilitation of learning: providing timely feedback, assigning group projects, and course assignments. Exemplar participant responses to Open-Ended Question 2 representing each theme included the following:

P18: "I give immediate feedback so students will know they are on the right track."

P33: "We break into small groups where students who are physically present communicate with those who are present electronically to complete group brainstorming and problem-solving projects."

P62: "I usually assign a reading topic or video viewing, followed by an online pretest, so that students get the basic information required to meet course objectives. Then I develop a project, a group discussion board, or other active learning strategy to apply or manipulate the concepts for deeper learning."

Direct instruction. Open-Ended Question 3 asked the following: Please describe how you provide direct instruction for students. For example, what teaching methods have worked well to focus discussion on relevant issues, provide constructive feedback, evaluate students' understanding, and direct students to a deeper level of understanding? The Adapted CoI Survey Instrument Quantitative Questions 11 through 13 provided the framework for Open-Ended Question 3. The qualitative data were analyzed to identify emerging categories.

Of the 86 study participants, $82.6 \%(n=71)$ responded to Open-Ended Question 3. Three major categories emerged describing teaching presence behaviors of direct instruction: providing constructive feedback, student and faculty participation in discussion forum, and assigning guided and active learning assignments. Interestingly, some participants shared that direct instruction in 
the blended or online environment is challenging. Exemplar participant responses to Open-Ended Question 3 representing each theme include the following:

P4: "I give students both positive and constructive feedback to help them know where they stand at all times. Further, I will let students know when they can go further with their information to take it to a challenging level...which is where they will grow...."

P22: "Regular engagement in the discussion board highlighting key points from student posts and suggesting additional things to think about. Group projects where students have to work together to solve real world problems, WebEx discussions to answer questions and make sure students are understanding the material. Online quizzes and tests to encourage students to stay current with assigned readings and to gauge understanding. Case studies have been very instructive."

P59: "One example is clinical notes - rather than just grade a clinical note, I use a 3 chance pass/fail approach. The student has to make corrections and learn from their mistakes, rather than just earning a grade. The constructive feedback with an opportunity to correct their note really helps them reach a deeper level of understanding."

\section{Discussion}

The findings of this study indicated a statistically significant difference between perceived teaching presence of facilitation score of educators that received on-the-job training as compared to educators that completed a certification course. When levels of preparation were compared, the study did not reveal a statistically significant relationship between educators' preparation to teach and overall teaching presence or between teaching presence of design and organization. This could indicate that the most significant differences in teaching face-to-face and teaching online occur during in-course activities, rather than during precourse activities of course development and planning. Qualitative responses support the statistically significant difference in perceived teaching presence of facilitation between participants that received informal on-the-job training only and those that completed a certification course in preparation to teach blended and online courses. For example, participants that reported completing a certification course in preparation to teach blended and online courses reported the following when asked to describe how the participant facilitates learning:

P1: "I respond to any questions promptly. I state if I do not respond to you in 24 hours, your email or question has been overlooked, please send an email again OR call OR text me. Within course content, I jump in for discussions. I respond and make comments along the way with discussions. I let my students know that I am there. I email questions regarding specific topics that are heavy in the discussions. I always remind students to email or call me for clarification of topics. I remind students who have not completed certain tasks, that the deadline is approaching soon and contact me ASAP if they have an issue. I also communicate in the beginning that we all have lives and things change--- please just communicate with me!!" 
P14: "Incorporating learning style approaches to provide multiple options for student driven learning. Formative assessment to provide multiple checkpoints. Discussion boards to assess level of understanding. Student driven teaching to allow students to apply new skill sets. Adult Learning Theory to maintain learner driven outcomes and competency development."

P28: "One of the primary modes for engaging students in the course content is online discussions. Students are encouraged to select a topic that represents knowledge they would like to develop or enhance. They research the topic and then post a summary presentation. Each student is then expected to engage in active dialogue with classmates regarding the presentations. Discussion instructions clearly indicate what should be included in the presentation. A date is identified for the initial presentation with responses being due by close of the next week's class day. A rubric indicating criteria for grading the discussions is posted and applied to all discussions. To achieve full credit for a discussion students must provide substantive responses that are supported by personal experiences and information from the texts and literature. I also include two additional discussion forums to support engagement and clarify understanding: (1) Ask the Professor, and (2) Student Lounge. The Ask the Professor forum provides an opportunity for students to ask overall questions regarding the course or assignments. Other students can see the question as well as my answer. The Student Lounge forum provides an opportunity for students to ask each other questions, share major life events, etc. It is often used when students ask for prayer during difficult times or share news of a child's wedding or birth."

In contrast, participants that reported receiving informal on-the-job training as preparation to teach blended and online courses described the following activities when asked to describe how the participant facilitates learning:

P9: "I provide opportunities for students to use videos, YouTube, discussion board, and grouping."

P36: "Require students read corresponding assignment as well as summarize a scholarly article they find related to the topic and post in discussion. Students respond to each other's posts. Reminder e-mails about upcoming due dates are sent. Asking students questions about what they post."

P52: "Projects work well for my classes. I give online exams. I have eliminated required posts from students based on student feedback that they do not feel the required posts are helpful."

The teaching presence of facilitation requires greater reliance on pedagogies and learning theories. Baran et al. (2013) recognized "increasing teacher presence for monitoring students' learning" and "reconstructing student-teacher relationships" as the greatest areas of pedagogical change when teachers transition from face-to-face teaching to teaching online (p. 5). This is supported by one participant's response regarding teaching behaviors of facilitation:

P30: "This is the hardest part of teaching online. I've created talking head videos of myself to go along with each module that work pretty well. I also have discussion boards that students are required to participate in. I haven't had much success using 
synchronous instruction. There always seems to be a technical difficulty or time management issue. Probably the greatest tool I use for communicating, keeping students on task, etc. is email."

These findings are congruent with the literature indicating that educators' preparation to teach in blended and online learning environments influences educators' perceptions of how well they facilitate learning. This study of educators' preparation to teach, perceived teaching presence, and perceived teaching presence behaviors in blended and online learning environments supports the need for faculty preparation specific to facilitating learning in blended and online courses. The results of this study indicate that faculty that completed a certification course in preparation to teach blended and online courses perceived greater teaching presence of facilitation as compared to faculty that only received on-the-job training. This study also supported the Adapted CoI Survey Instrument as a valid tool to measure educators' perceptions of teaching presence and the teaching presence indicators of direct instruction and facilitation.

With the increasing trend for blended and online courses in higher education (American Association of Colleges of Nursing, 2003; McDonald \& Picciano, 2014; U.S. Department of Education, 2014), the results of this study offer several implications for educators and administrators of universities that traditionally have not offered blended and online courses. For example, educators transitioning from the face-to-face learning environment to the online learning environment must understand the challenges of facilitating learning when separated by time and place. Faculty must learn and implement innovative ways of communicating meaningful feedback to students.

In addition, this study supports the importance of assessing how the current culture of the institution supports and affects teaching in nontraditional learning environments (Baran \& Correia, 2014). As Ali et al. (2005) indicated, quality faculty development programs must be established to support faculty involved in developing and teaching online courses. Although many professional development opportunities are available to prepare educators to teach in blended and online learning environments, these are often limited to learning how to use the technology (Lane, 2013). The greatest need for educators teaching in blended and online learning environments is learning how to apply pedagogies that support a variety of technologies (Lane, 2013). Administrators must assess the needs of faculty teaching in blended and online learning environments and then provide professional development programs that address the identified needs.

\section{Study Limitations}

Limitations of this study were related to the sample population. The sample population was limited to a convenience sample of full-time, part-time, and adjunct faculty employed in two private universities in the southeastern United States; therefore, results could not be generalized beyond the study population. It is likely that differences in technology infrastructure, faculty resources, and administrative support exist between private and public universities. In addition, the study did not consider the possible influences of length of teaching experience or employment status on educators' perceived teaching presence. 


\section{Conclusions}

As one of the first studies exploring the relationship between educators' perceived teaching presence and preparation to teach, the findings of this study have significant implications for faculty development programs in higher education. This study revealed a statistically significant relationship between perceived teaching presence of facilitation and completion of a certification course in online instruction as compared to those receiving on-the-job training only, indicating that how educators are prepared to teach influences their perceptions of how well they facilitate learning. Although this study did not explore reasons for the increased perception, consideration of characteristics of certification courses might provide conceptual insight into why participants indicated greater perception of facilitating learning in the online environment. Certified online instructor courses are intensive and comprehensive, requiring participants to commit anywhere from 9 weeks to 6 months or longer to complete learning and evaluation activities related to learner-centered pedagogies specific to teaching in the online learning environment. Participants experience online learning from the student's perspective, exploring common challenges to facilitating online learning, as well as theory-based methods for addressing these challenges. Participants must interact with technologies used in online courses and learn how to implement supporting pedagogies. Networking opportunities are provided, thus promoting faculty bonding and support during the transition from face-to-face to online educator. Lastly, some certification courses include an end-of-program certification exam and critique of participants' online courses. Perhaps it is the dedication of faculty completing these rigorous certification courses, immersion in pedagogies specific to online learning, peer support, and increased self-efficacy as an online educator that influences perceived teaching presence of facilitation.

The findings support the assertion that educators that complete formal training programs, such as certification courses, are more confident in their abilities to facilitate student learning in blended and online courses. Higher education administrators must invest in faculty development and mentoring programs that teach pedagogies and teaching presence behaviors specific to distance education environments. Administrators must consider the time required and foundational knowledge and skills necessary for faculty to engage in behaviors that facilitate teaching presence. Future research should explore how to best support faculty transitioning from teaching face-toface to teaching in blended and online learning environments. Perhaps exploration of the overarching concepts included in certification courses will provide a strong foundation for faculty development programs that include content development, learning activities, teaching strategies, and assessment techniques based on pedagogies best suited for blended and online learning environments.

\section{Acknowledgements}

This research was completed as requirements for the Doctor of Philosophy in Nursing Education and Administration degree at William Carey University, Hattiesburg, Mississippi. I would like to acknowledge my dissertation committee, Dr. Elizabeth Mahaffey (chair), Dr. Ashley Krebs (faculty advisor), Dr. LaWanda Herron (member), and Dr. Jaylyn Roberts (member, statistician). 
Educators' Preparation to Teach, Perceived Teaching Presence, and Perceived

Teaching Presence Behaviors in Blended and Online Learning Environments

\section{References}

Akyol, Z., \& Garrison, R. (2008). The development of a community of inquiry over time in an online course: Understanding the progression and integration of social, cognitive, and teaching presence. Journal of Asynchronous Learning Networks, 12(3-4), 3-22. Retrieved from http://olj.onlinelearningconsortium.org/index.php/jaln

Ali, N. S., Hodson-Carlton, K., Ryan, M., Flowers, J., Rose, M. A., \& Wayda, V. (2005). Online education: Needs assessment for faculty development. The Journal of Continuing Education in Nursing, 36(1), 32-38. Retrieved from http://www.healio.com/nursing/journals/jcen

Allen, I. E., \& Seaman, J. (2013). Changing course: Ten years of tracking online education in the United States. Babson Survey Research Group and Quahog Research Group, LLC. Retrieved from http://www.onlinelearningsurvey.com/reports/changingcourse.pdf

Allen, I. E., Seaman, J., Poulin, R., \& Straut, T. T. (2016). Online report card: Tracking online education in the United States. Babson Survey Research Group and Quahog Research Group, LLC. Retrieved from http://onlinelearningsurvey.com/reports/onlinereportcard.pdf

American Association of Colleges of Nursing. (2003). Alliance for accreditation statement on distance education policies. Retrieved from http://www.aacn.nche.edu/educationresources/distance-education-policies

Anderson, T., Rourke, L., Garrison, D. R., \& Archer, W. (2001). Assessing teaching presence in a computer conferencing context. The Journal of Asynchronous Learning Networks, 5(2), 1-17. Retrieved from http://olj.onlinelearningconsortium.org/index.php/jaln

Arbaugh, J. B. (2008). Does the community of inquiry framework predict outcomes in online MBA courses? International Review of Research in Open and Distance Learning, 9(2), 1-21. Retrieved from http://www.irrodl.org/index.php/irrodl/index

Arbaugh, J. B., Cleveland-Innes, M., Diaz, S. R., Garrison, D. R., Ice, P., Richardson, J. C., \& Swan, K. P. (2008). Developing a community of inquiry instrument: Testing a measure of the community of inquiry framework using a multi-institutional sample. The Internet and Higher Education, 11(3-4), 133-136. doi:10.1016/j.iheduc.2008.06.003

Arinto, P. B. (2013). A framework for developing competencies in open and distance learning. The International Review of Research in Open and Distance Learning, 14(1), 167-185. Retrieved from http://www.irrodl.org/index.php/irrodl

Baran, E., \& Correia, A. (2014). A professional development framework for online teaching. TechTrends, 58(5), 96-102. Retrieved from http://link.springer.com/journal/11528

Baran, E., Correia, A., \& Thompson, A. D. (2013). Tracing successful online teaching in higher education: Voices of exemplary online teachers. Teachers College Record, 115, 1-41. Retrieved from http://www.tcrecord.org/

Bolliger, D. U., \& Wasilik, O. (2009). Factors influencing faculty satisfaction with online teaching and learning in higher education. Distance Education, 30(1), 103-116. doi:10.1080/01587910902845949 
Campbell, D. E. (2014). The influence of teacher immediacy behaviors on student performance in an online course (and the problem of method variance). Teaching of Psychology, 41(2), 163-166. doi:10.1177/0098628314530351

Carlon, S., Bennett-Woods, D., Berg, B., Claywell, L., LeDuc, K., Marcisz, N., ... Zenoni, L. (2012). The community of inquiry instrument: Validation and results in online health care disciplines. Computers \& Education, 59(2), 215-221.

doi:10.1016/j.compedu.2012.01.004

Costello, E., Corcoran, M., Barnett, J. S., Birkmeier, M., Cohn, R., Ozgur, E., ... Walker, B. (2014). Information and communication technology to facilitate learning for students in health professions: Current uses, gaps, and future directions. Online Learning, 18(4), 118. Retrieved from http://olj.onlinelearningconsortium.org/index.php/jaln

Creswell, J. S. (2014). Mixed methods procedures. In Research design: Qualitative, quantitative, and mixed methods approaches (4th ed., pp. 215-240). Los Angeles, CA: SAGE Publications, Inc.

Creswell, J. W., \& Plano Clark, V. L. (2011). Choosing a mixed methods design. In Designing and conducting mixed methods research (2nd ed., pp. 53-106). Thousand Oaks, CA: SAGE Publications, Inc.

Dereshiwsky, M. (2013). Continual engagement: Fostering online discussion. RiverFalls, WI: LERN Books.

Garrison, D. R., Anderson, T., \& Archer, W. (2000). Critical inquiry in a text-based environment: Computer conferencing in higher education. The Internet and Higher Education, 2(2-3), 87-105. doi:10.1016/S1096-7516(00)00016-6

Garrison, D. R., \& Cleveland-Innes, M. (2005). Facilitating cognitive presence in online learning: Interaction is not enough. American Journal of Distance Education, 19(3), 133148. doi:10.1207/s15389286ajde1903_2

Garrison, D. R., Cleveland-Innes, M., \& Fung, T. S. (2010). Exploring causal relationships among teaching, cognitive and social presence: Student perceptions of the community of inquiry framework. The Internet and Higher Education, 13(1-2), 31-36. doi:10.1016/j.iheduc.2009.10.002

Lane, L. (2013). An open, online class to prepare faculty to teach online. Journal of Educators Online, 10(1), 1-31. Retrieved from http://thejeo.com/

Luo, T., Hibbard, L., Franklin, T., \& Moore, D. R. (2017). Preparing teacher candidates for virtual field placement via an exposure to K-12 online teaching. Journal of Information Technology Education: Research, 16. Retrieved from http://www.jite.org/documents/Vol16/JTEv16ResearchP001-014Lu03094.pdf

MaCorr Research Solutions Online. (2015). Sample size calculator. Retrieved from http://www.macorr.com/sample-size-calculator.htm

McDonald, P. L., \& Picciano, A. G. (2014). Introduction to the special issue on blended learning in the health sciences. Online Learning, 18(4), 7-11. Retrieved from http://olj.onlinelearningconsortium.org/index.php/jaln 
Moore, J. C. (2010). A synthesis of SLOAN-C effective practices. Journal of Asynchronous Learning Networks, 14(3), 24-45. Retrieved from http://files.eric.ed.gov/fulltext/EJ971042.pdf

O’Neil, C. A. (2014). Introduction to teaching and learning in online environments. In C. A. O’Neil, C. A. Fisher, \& M. J. Rietschel (Eds.), Developing online learning environments in nursing education (3rd ed., pp. 1-13). New York, NY: Springer Publishing Company, LLC.

Rovai, A. P., \& Jordan, H. M. (2004). Blended learning and sense of community: A comparative analysis with traditional and fully online graduate courses. The International Review of Research in Open and Distributed Learning, 5(2), 1-8. Retrieved from http://www.irrodl.org/index.php/irrodl/article/view/192/274

Ryan, M., Hodson-Carlton, K., \& Ali, N. S. (2004). Reflections on the role of faculty in distance learning and changing pedagogies. Nursing Education Perspectives, 25(2), 73-80. Retrieved from http://www.nln.org/newsroom/newsletters-and-journal/nursing-educationperspectives-journal

Sadera, W. A., O’Neil, C. A., \& Gould, K. A. (2014). Pedagogy associated with learning in online environments. In C. A. O’Neil, C. A. Fisher, \& M. J. Rietschel (Eds.), Developing online learning environments in nursing education (3rd ed., pp. 15-28). New York, NY: Springer Publishing Company, LLC.

Saint-Jacques, A. (2013). Effective teaching practices to foster vibrant communities of inquiry in synchronous online learning. In Z. Akyol \& R. Garrison. Educational communities of inquiry: Theoretical framework, research, and practice (pp. 84-108). Hershey, PA: IGI Global.

Shea, P., \& Bidjerano, T. (2009). Community of inquiry as a theoretical framework to foster "epistemic engagement" and "cognitive presence" in online education. Computers \& Education, 52(3), 543-553. doi:10.1016/j.compedu.2008.10.007

Shea, P., Li, C. S., Swan, K., \& Pickett, A. (2005). Developing learning community in online asynchronous college courses: The role of teaching presence. Journal of Asynchronous Learning Networks, 9(4), 59-82. Retrieved from http://onlinelearningconsortium.org/read/online-learning-journal/

Shea, P., Vickers, J., \& Hayes, S. (2010). Online instructional effort measured through the lens of teaching presence in the community of inquiry framework: A re-examination of measures and approaches. International Review of Research in Open and Distance Learning, 11(3), 127-153. Retrieved from http://www.irrodl.org/index.php/irrodl

Shepherd, C. E., Bolliger, D. U., Dousay, T. A., \& Persichitte, K. (2016). Preparing teachers for online instruction with a graduate certificate program. TechTrends, 60, 41-47. Retrieved from https://link.springer.com/journal/11528

Sheridan, K., Kelly, M. A., \& Bentz, D. T. (2013). A follow-up study of the indicators of teaching presence critical to students in online courses. In Z. Akyol \& R. Garrison. Educational communities of inquiry: Theoretical framework, research, and practice (pp. 67-83). Hershey, PA: IGI Global. 
Swan, K., Garrison, D. R., \& Richardson, J. C. (2009). A constructivist approach to online learning: The community of inquiry framework. In C. R. Payne (Ed.) Information technology and constructivism in higher education: Progressive learning frameworks (pp. 43-57). Hershey, PA: IGI Global. Retrieved from http://www.cosa.k12.or.us/sites/default/files/docs/constructivisim.pdf

Swan, K. P., Richardson, J. C., Ice, P., Garrison, D. R., Cleveland-Innes, M., \& Arbaugh, J. B. (2008). Validating a measurement tool of presence in online communities of inquiry. $E$ mentor, 2(24), 1-12. Retrieved from www.e-mentor.edu.pl/eng

United States Department of Education. (2014). Enrollment in distance education courses, by state: Fall 2012. Retrieved from http://nces.ed.gov/pubs2014/2014023.pdf

Vogt, W. P., Gardner, D. C., \& Haeffele, L. M. (2012). When to use survey designs. In When to use what research design (pp. 15-30). New York, NY: The Guilford Press. 